\title{
NANOMECHANICAL PROPERTIES AND POSSIBLE APPLICATIONS OF MECHANOACTIVATED ZnO COATINGS
}

\author{
R. Zabels, F. Muktepavela, M. Chubarov \\ Institute of Solid State Physics, University of Latvia \\ 8 Kengaraga Str., LV-1063, Riga, LATVIA \\ e-mail: famuk@latnet.lv
}

\begin{abstract}
A simple and cost-effective mechanoactivated oxidation method (MAOM) has been developed for producing $\mathrm{ZnO}$ coatings on glass. To achieve the transparency of initially opaque mechanoactivated $\mathrm{ZnO}$ coatings they were annealed at the temperatures modifying the surface morphology of nanostructured coatings. Investigation of nanomechanical properties has revealed that MAOM coatings in as-obtained state have higher hardness (up to $3 \mathrm{GPa}$ ) as compared with bulk metallic zinc (160 MPa). In the annealed state the coatings show stabily high adhesion with glass, with the ability to form a grained structure (hardness 8-10 GPa) or a whiskers nanostructure (hardness 18-20 GPa). The Young modulus of coatings ranged from 80 to $120 \mathrm{GPa}$. The nanomechanical and optical properties were compared with those of bulk $\mathrm{ZnO}$ single crystal and commercial $\mathrm{ZnO}$ films. The optical properties of $\mathrm{ZnO}$ films with a whiskers structure are typical of a transparent high-quality $\mathrm{ZnO}$ single crystal. The coatings obtained have high electrical resistance, which decreases in response to the UV exposure. The photocurrent increases by two orders of magnitude, which is easily detectable and makes it possible to use such coatings as UV emission detectors.
\end{abstract}

Key words: $\mathrm{ZnO}$ films, nanoindentation, UV photodetector.

\section{INTRODUCTION}

$\mathrm{ZnO}$ is a functionally interesting material with various morphologies, which can be controlled during the growth processes. Each of them exhibits different properties, and therefore fields of application are highly diversified. Since $\mathrm{ZnO}$ is a semiconductor, this has already found application in electronics (varistors and surface wave filters), solar panels (transparent conducting electrodes), sensors (photo, gas), etc. - wherever not a bulk material is required but instead thin films are preferred.

Several techniques have been developed to prepare $\mathrm{ZnO}$ films with specific structure and physical properties for certain applications (PLD, PVD, CVD, etc.) [1-4]. In particular, a simple and low-cost method is thermal oxidation of deposited $\mathrm{Zn}$, which has recently become of considerable interest [4-8]. In the listed reports metallic $\mathrm{Zn}$ thin films were deposited on various substrates (glass, silica, sapphire) using RF magnetron sputtering, electron-beam evaporation or thermal deposition methods, which are power-intensive. It should be noted that the quality of $\mathrm{ZnO}$ films obtained by thermal oxidation strongly depends both on deposition and subsequent annealing conditions. For example, the quality of coatings prepared by the RF magnetron sputtering method depends on 5-6 parameters; as concerns the 
thermal deposition method, it does not provide a good adhesion of metals with glass. To widen the scope for application, apart from the economical aspect the problem is to achieve the necessary correlation of a $\mathrm{ZnO}$ coating microstructure with its properties $[7,9,10]$. To provide a good mechanical stability of devices a deep insight is needed into the $\mathrm{ZnO}$ mechanical properties (adhesion included) on a nano- and microscale. So far these aspects have received very little attention.

In our work, a method based on the mechanoactivated oxidation has been applied for producing nanostructured transparent thin $\mathrm{ZnO}$ coatings. Our idea was to use the nanostructured state of metal at the moments of sample rupture in the ambient atmosphere at room temperature (RT) followed by transfer of ruptured and oxidized particles to the substrate. This idea could be realized in obtaining $\mathrm{Zn}-\mathrm{ZnO}$ based coatings using a fast rotating steel wire brush at RT [11, 12]. The destructed metal is nanostructured, and contains a net of dislocations, grain boundaries, and microcracks with atomically clean surfaces [13] that can promote oxygen diffusion and reactive processes. By the subsequent annealing, a $\mathrm{Zn}-\mathrm{ZnO}$ nanocomposite coating can be modified into a completely oxidized $\mathrm{ZnO}$ with different microstructure using only the annealing temperature as the main factor. Zink is known to be relatively easily oxidized $\left(\Delta \mathrm{G}_{293}=-318 \mathrm{~kJ} / \mathrm{mol}\right)$, so diffusion of oxygen through $\mathrm{ZnO}$ is not complicated. Such mechanoactivated oxidation is simple and costeffective; this method also provides good adhesion due to formation of a narrow reaction zone in the interface, which was reported earlier for $\mathrm{Al}, \mathrm{Cu} /$ glass systems [11].

\section{EXPERIMENTAL}

\subsection{Film deposition}

A $0.5-2 \mu \mathrm{m}$ thick coating was obtained at RT using a fast rotating steel wire brush (1400 rpm) for about $5 \mathrm{~min}$., without expensive complex equipment. Polycrystalline $\mathrm{Zn}(99.99 \mathrm{wt} \%)$ was chosen as the source material for coatings, while sodium-silicate and lithium-borate glass was used as the substrate. The annealing experiments were conducted at $460-780{ }^{\circ} \mathrm{C}(20-40 \mathrm{~min})$ in ambient atmosphere.

\subsection{Microhardness measurements}

Microhardness indentation experiments were carried out using a uniquely modified PMT-3 microhardness tester [14]. Its loading mechanism was remade in such a way that the applied load is disengaged from the main frame and rests on a sample freely due to gravity. Such a design allows very low loads to be used (starting from $1.2 \mathrm{mN}$ ), which is determined by the mass of a weight holder and a shaft. In the microhardness test, a Vickers pyramidal diamond tip was used. The hardness was calculated as

$$
H_{V}=1854 \frac{P}{d^{2}} \text {, }
$$

where $P$ is the applied load in grams, and $d$ is the diagonal length of residual imprint in micrometers. 


\subsection{Nanomechanical properties}

Another technique was employed to characterize the nanomechanical properties of samples. The MTS Nano G200 indenter uses direct continuous load and displacement registration. Its resolution is better than $0.01 \mathrm{~nm}$, the maximum indentation depth is greater than $500 \mu \mathrm{m}$, the maximum load is $500 \mathrm{mN}$, and the load resolution is $50 \mathrm{nN}$. The data obtained allow not only hardness but also Young's modulus to be derived. The loading-unloading curve also provides information about plastic deformation - in a more general way. The Young modulus and hardness are calculated from the unloading curve using the OliverPharr model [15]. Our MTS Nano G200 nanoindentor is also provided with a continuous stiffness module that allows registering the modulus and hardness as functions of the penetration depth. All indentation experiments were carried out using a Berkovich diamond indenter tip (radius $<20 \mathrm{~nm}$ ).

\subsection{Optical and electrical properties}

To characterise the optical properties of the obtained coatings a device for absorption spectra registration (Specord 200) was used. The photoluminescence spectra were obtained at RT and also at $12 \mathrm{~K}$ using a nitrogen laser for excitation and a Hamamatsu photon counting head for the luminescence registration.

The volt-ampere characteristics were measured using a Keithley 2000 voltmeter and a Keitley 6485 ammeter. The variable voltage was supplied by an Agilent 33220A function generator.

\section{RESULTS AND DISCUSSION}

\subsection{Morphology}

At the annealing temperature of $\sim 480{ }^{\circ} \mathrm{C}$ the obtained opaque coatings transform to transparent $\mathrm{ZnO}$ coatings. Up to $\sim 550{ }^{\circ} \mathrm{C}$ the dominating morphology is grains. After this temperature had been reached, a growth of individual whiskers was observed. At $650{ }^{\circ} \mathrm{C}$ the whole surface was covered with whiskers, and this was found to be the optimal temperature for whisker morphology. Nevertheless, underneath the whisker layer still grains could be observed. The increase in temperature led even more to disappearance of whiskers and recrystallisation of grains - they grew larger in size. The maximum annealing temperature was set $780^{\circ} \mathrm{C}$, since at higher temperatures the glass substrate started to melt and overflow the obtained coating.

\subsection{Mechanical properties}

Microhardness measurements were taken before (Fig. 1a) and after (Fig. 1b) annealing. Before annealing, the measured microhardness was rather high ( $3 \mathrm{GPa})$ near surface, and decreased with indentation depth, reaching the minimum and then rising up to the value characteristic of a glass substrate. It might seem untypical, since the hardness of metallic $\mathrm{Zn}$ is around $0.4 \mathrm{GPa}$; however, as seen from XRD data [12], even before annealing there were found traces of $\mathrm{ZnO}$, which is a plausible explanation for the elevated hardness. This proves once more that nonannealed MAOM coating has a composite structure $-\mathrm{Zn}-\mathrm{ZnO}$.

The microhardness measurements on annealed samples showed a structural dependence. The highest hardness was obtained for samples with a whisker struc- 
ture - up to $18 \mathrm{GPa}$. For the samples with grained structure this value ranged from 6 to $10 \mathrm{GPa}$. The high hardness of the whisker structure can be explained by the fact that these little crystals are almost ideal, and their volume is so small that it is difficult for a dislocation loop to form. As is known, this is determined by the threshold strain [16]:

$$
\tau_{d i s l}=\frac{G \cdot b}{d},
$$

where $G$ is the shear modulus, $b$ is Burgers' vector, and $d$ is the size of crystal.

During the microhardness experiments we also observed that our coatings had great adhesion to the substrate. When high loads $(>2000 \mathrm{mN})$ were applied in the measurements no signs of coating detachment were seen. We consider this property beneficial as compared with other oxidation methods.
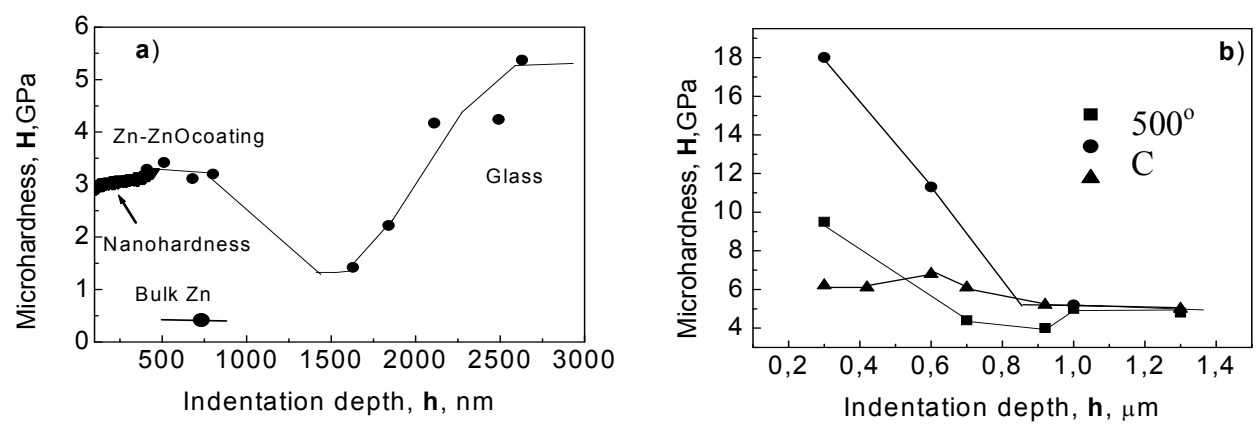

Fig. 1. Microhardness measurements on MAOM samples: before ( $a$ ) and after $(b)$ annealing.

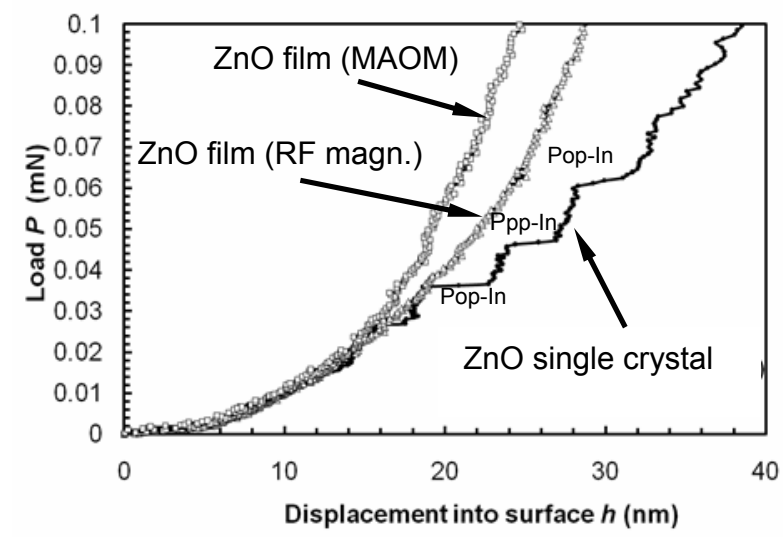

Fig. 2. Comparison of indentations performed in $\mathrm{ZnO}$ single crystal and in $\mathrm{ZnO}$ nanostructured films obtained by MOAM and RF magnetron deposition.

For $\mathrm{ZnO}$ single crystal the increase in depth at constant load ("Pop-In") owing to nucleation and spread of dislocations is observed.

In turn, nanohardness tests appeared to be complicated - no reasonable results were obtained on the samples with whisker morphology. It can be explained by the fact that the Berkovich indenter is sharper, so on nanoscale the porosity is the main cause for incorrect sensing of the $\mathrm{ZnO}$ layer. As is seen in Fig. 1a, on the 
samples with grained morphology high values for hardness (9 GPa) and Young's modulus $(120 \mathrm{GPa})$ were obtained. We also experimented with $\mathrm{ZnO}$ :Ga coating samples from "Sidrabe" Inc., which were obtained by magnetron sputtering. The measurements on these samples gave $9 \mathrm{GPa}$ for hardness and $125 \mathrm{GPa}$ for Young's modulus. These values are in good agreement with our MAOM coatings, and they also coincide well with those reported in other publications (see, e.g. [4, 17]). Another opportunity was to take measurements on a $\mathrm{ZnO}$ single crystal and to analyse its loading curve. When compared with the MAOM and magnetron sputtered coatings (Fig. 2), the difference is obvious - the single crystal exhibits a typical mechanism of plastic deformation; in the loading range it contains discontinuities, which is evidence for dislocation movement. Such behaviour was not observed for the MAOM and magnetron sputtered coatings, which means that there are involved other deformation mechanisms; this also shows that there is sufficiently greater dislocation origin strain.

\subsection{Optical properties}

The optical absorption and photoluminescence (PL) are good tools for testing the quality of coatings and for further application possibilities both in optoelectronics and power engineering. We use these methods for characterization of the obtained $\mathrm{ZnO}$ transparent coatings. The optical absorption spectra show that the coatings are transparent in the spectral region 2.2-3.0 eV (Fig. 3). For the coatings annealed at $\mathrm{T}>600{ }^{\circ} \mathrm{C}$ the transparency at $2.5 \mathrm{eV}$ was $80 \%$. The best results were achieved for the samples annealed at $650^{\circ} \mathrm{C}$.

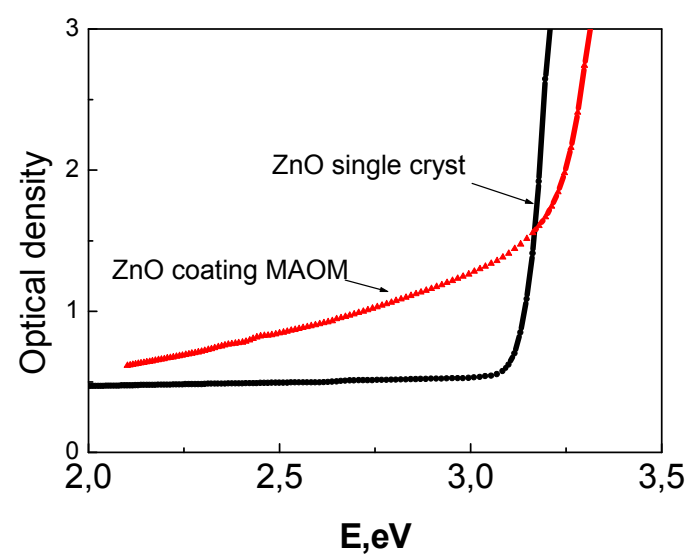

Fig. 3. Absorption spectra of $\mathrm{ZnO}$ single crystal and $\mathrm{ZnO}$ coating obtained by the mechanoactivated oxidation method (MAOM).

Figure $4 a$ shows the PL spectra measured at $300 \mathrm{~K}$ and $12 \mathrm{~K}$ for a $\mathrm{ZnO}$ coating obtained after annealing at $650{ }^{\circ} \mathrm{C}$. The spectrum at $300 \mathrm{~K}$ is close to the well-known PL spectrum for single crystal $[9,19]$. The wide diffused band at 2.2$2.8 \mathrm{eV}$ (green luminescence) with low PL intensities is related to the oxygen vacancies. The high-intensity luminescence band at $3.26 \mathrm{eV}$ (blue luminescence) is LO-phonon associated free exciton luminescence (1LO-Ex). In the spectra measured at $12 \mathrm{~K}$ (see insert in Fig. $4 a$ ) the main band due to exciton bound at neutral donor $\left(\operatorname{ExD}^{0}\right)$ and its phonon replica $\left(1 \mathrm{LO} \_\operatorname{ExD}^{0}\right)$ were observed. The lumi- 
nescence decay in exciton bands is very fast. Similar spectra and decay times are known for $\mathrm{ZnO}$ single crystals and whisker structures [9, 18-20]. Figure $4 b$ presents the photoluminescence spectra of $\mathrm{ZnO}$ single crystal measured at $12 \mathrm{~K}$. Without going into deeper detail of the results obtained at other temperatures, we could notice that in the case of formation of nanograined structures the intensity of the defect-related band increased probably owing to the presence of residual zinc. Such results were obtained by us earlier [12].

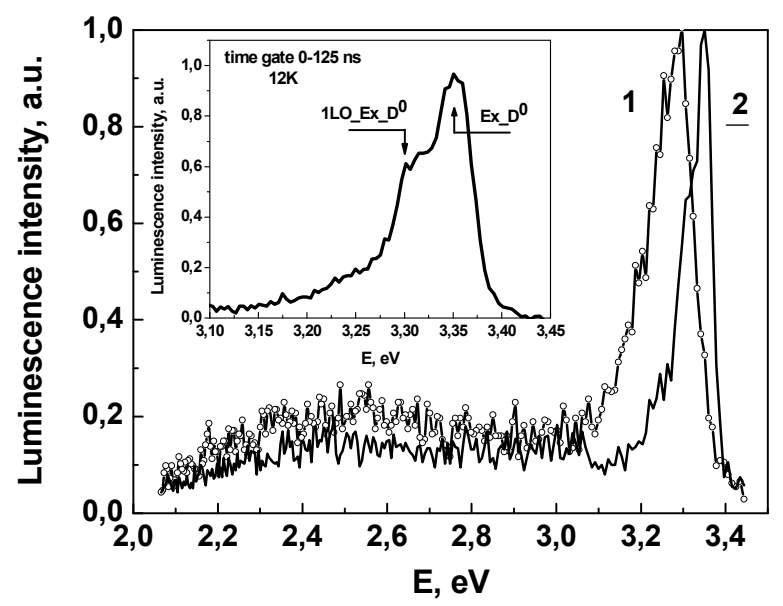

a)

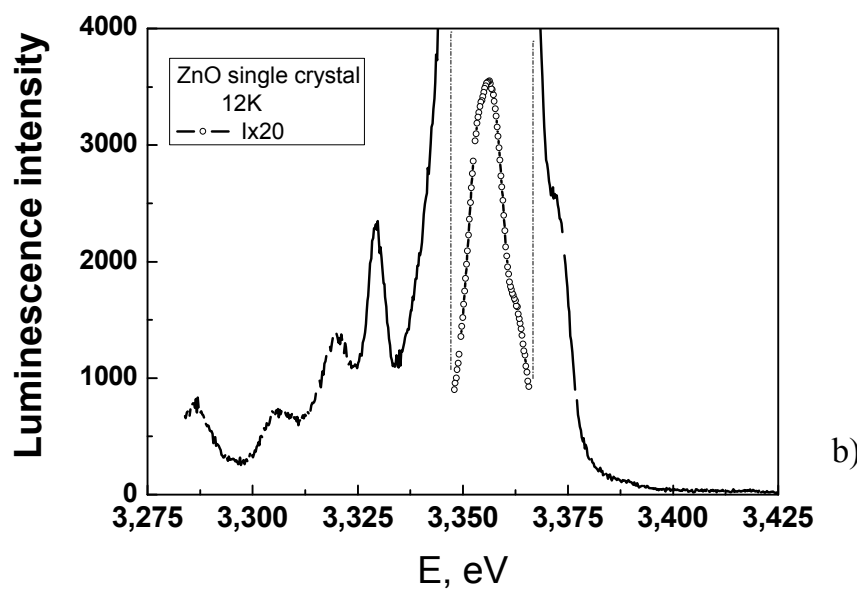

Fig. 4. The photoluminescence spectra of annealed at $923 \mathrm{~K} \mathrm{ZnO}$ coating measured with time gate $2.5 \mu$ s at $300 \mathrm{~K}(1)$ and $12 \mathrm{~K}(2)$. Insert: fast excitonic (time gate $125 \mathrm{~ns}$ ) luminescence at $12 \mathrm{~K}(a)$; the photoluminescence spectra of $\mathrm{ZnO}$ single crystal at $12 \mathrm{~K}(b)$.

Since the positions of $\mathrm{PL}$ bands of the $\mathrm{ZnO}$ coatings annealed at $650{ }^{\circ} \mathrm{C}$ coincide with those observed for single crystal and no additional PL bands were detected, we can conclude that the obtained $\mathrm{ZnO}$ films are of high quality. Zinc oxide is a wide-band-gap semiconductor having a high exciton binding energy of $60 \mathrm{MeV}$. These properties as well as the transparency of coatings in the visible part of spectrum, together with high thermal and chemical stability, make this material attractive for producing UV-emission detectors. For this purpose, a low concentration of intrinsic defects in $\mathrm{ZnO}$ is preferable [7]. 


\subsection{UV photodetection}

The MAOM ZnO films with whiskers structure have high resistance - its estimated values reach an order of $10^{7} \Omega \cdot \mathrm{cm}$. It is known that the best results of UV detection have been obtained for $\mathrm{ZnO}$ films with high resistance [21]. Most simple sample preparation was done for the volt-ampere characterisation. Two parallel 2 $\mathrm{mm}$ spaced silver electrodes were placed on the MAOM coating. Our measured voltage-current plots show that a good ohmic contact was achieved. The sample was characterised in a non-irradiated state (dark current) and during UV exposure (light current) (Fig. 5), which was done using a mercury vapour discharge lamp. It is seen that the light current is higher almost by two orders of magnitude. Such difference can easily be measured, allowing for applications in very small portable UV emission detectors. Further research into the best morphology (with the main factor being the annealing temperature) is yet to be done.
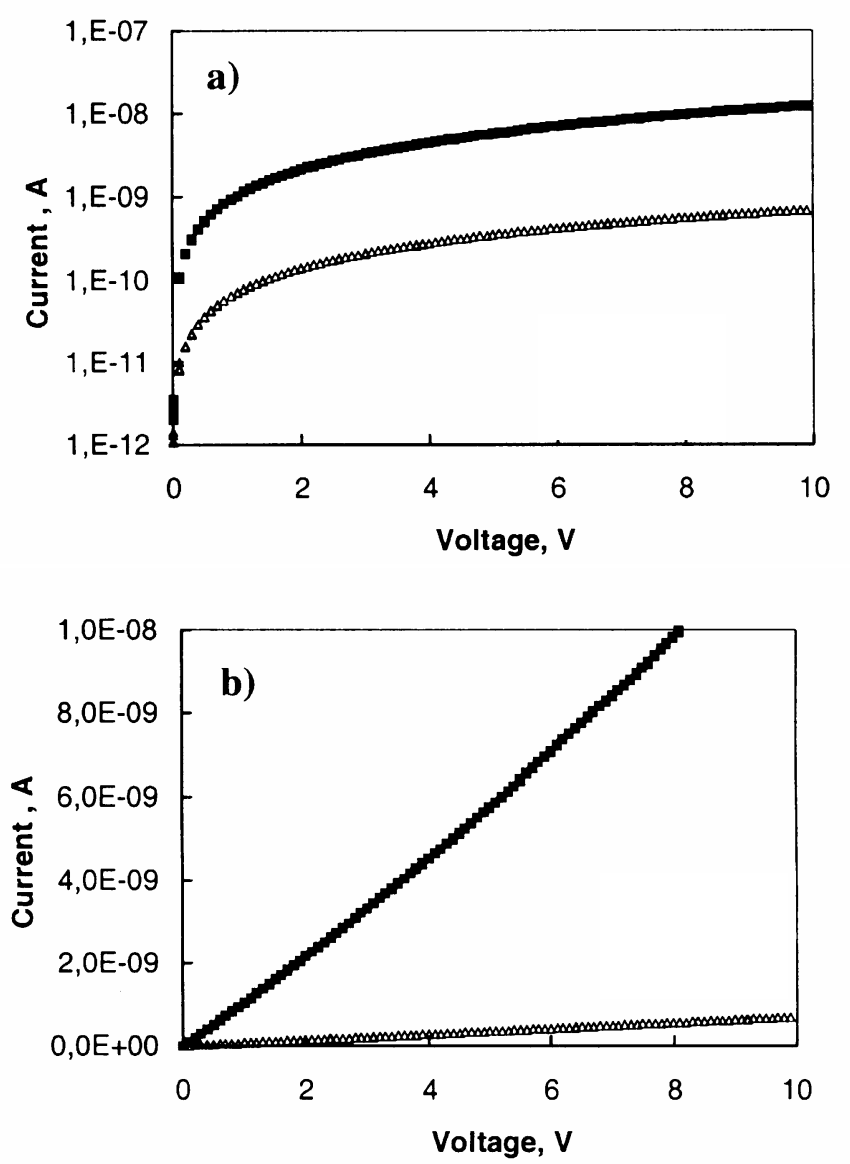

Fig. 5. Photocurrent dependence on the voltage applied to MAOM samples with whiskers structure: logarithmic scale $(a)$, linear scale $(b)$.

$\Delta$ dark current; $\square$ light current

\section{CONCLUSIONS}

The results of our experiments have shown that the mechanoactivated oxidation method is one of the simplest and economical methods for $\mathrm{ZnO}$ coating 
production. The obtained films have a very high adhesion to the substrate, which is a benefit if compared with other oxidation methods.

The hardness values, as seen from microhardness measurements, depend on the morphology, making up to 6-10 GPa for grained structures and up to $18 \mathrm{GPa}$ for the whiskers structure. The nanohardness values are around $9 \mathrm{GPa}$, with Young's modulus being $120 \mathrm{GPa}$. These values coincide with those for coatings obtained by magnetron sputtering technique and reported in the literature.

The optical properties of coatings with a whiskers structure are typical of high-quality transparent $\mathrm{ZnO}$ single crystals. The high-intensity luminescence band at $3.26 \mathrm{eV}$ (blue luminescence) is the LO-associated free exciton luminescence (1LO-Ex). In the spectra measured at $12 \mathrm{~K}$ the main band due to exciton bound at neutral donor $\left(\operatorname{ExD}^{0}\right)$ and its phonon replica $\left(1 \mathrm{LO} \mathrm{ExD}^{0}\right)$ were observed. The PL intensities related to the oxygen vacancies are very low.

The obtained coatings have high electric resistance, which decreases in response to the UV exposure. The change in photocurrent is almost two orders of magnitude, which is easily detectable and makes possible the use of these coatings as UV emission detectors.

\section{ACNOWLEDGEMENTS}

This work was financially supported by the Latvian Science Council (05.1705).

\section{REFERENCES}

1. Kim, J.S., Marzouk, H.A., \& Reucroft, P.J. (1992). Thin Solid Films, 217, 133.

2. Chen, J.J., Gao, Y., Zeng, F., Li, D.M., \& Pan, F. (2004). Appl. Surf. Sci., 223, 318.

3. Wang, Y.G., Lau, S.P., Lee, H.W. et al. (2003). J. Appl. Phys., 94, 354.

4. Fang, T.-H, Chang, W.-J, \& Lin, C.-M. (2007). Mater. Sci. Eng., 452, 715.

5. Li, Z.W., Gao, W., \& Reeves, R. (2005). Surf. \& Coat. Techn.,198, 319.

6. Kim S., Jeong M-C., Oh B-Y., Lee W., \& Myoung J.M. (2006). J.Cryst.Growth, 290, 485.

7. Zheng, X.G., \& Li, Q.S. (2008). Cent. Eur.J.Phys., 6, 351.

8. Jeong, M.C., Oh, B.Y., Lee, W., \& Myoung, J.M. (2004). J.Cryst. Crowth, 268, 149.

9. Özgur, Ü., Alivov, Ya.I., Liu, C., Teke, A., et al. (2005). J. Appl. Phys., 98, 041301.

10. Suchea, M., Christoulakis, S., Moschovis, K., Katsarakis, N., \& Kiriakidis, G. (2006). Thin Solid Films, 515, 551

11. Muktepavela F., Bakradze G., \& Stolyarova S. (2007). Phys. Stat. Sol.(c) 4, 740.

12. Muktepavela F., Bakradze G., \& Tamanis E. (2005). Phys.Stat.Sol (a) 2, 339.

13. Firstov S., Brodnikovsky M. et al. (2003). Rev. Adv. Mater. Sci. 4, 155.

14. Upit G.P., \& Varchennya, S.A. (1986). Scientific Instruments (ed I.G. Matis), Riga: Zinatne, p.12 (in Russian).

15. Oliver, W. C., \& Pharr, G. M. (1992). J. Mater. Res., 7, 1564.

16. Khan A., \& Huang, S.(1989). Continuum Theory of Plasticity. Amsterdam :Elsevier, 240.

17. Chang, S.Y., Hsiao, Y. C. \& Huang, Y. C., (2008). J. Surf. \& Coat. Techn., 202, 5416

18. Navamathavan, R., Kim, K. K., Hwang, D. K., et al. (2006). J. Appl. Surf. Phys., 253, 464-467.

19. Fan, H.J., Scholz, R.S., Kolb, F.M. \& Zacharias, M. (2004). Appl.Phys.Let., 85, 774. 
20. Grigorjeva, L., Millers, D., Grabis, J., Monby, C.J., Kalinko, A., Smits, K., Pankratov, V., \& Lojkovski, W. (2008). IEEE Transactions on Nuclear Sci., 128, 1551.

21. Krivchenko, V.A., Lopajev, D.V., Paschenko, P.V., Pirogov, V.G., Rahimov, A.T., Suetin, N.V., \& Trifonov, A.S. (2008). Zhurnal Tekhnicheskoi Fiziki, 78 (8), 305 (in Russian).

\section{MEHANOAKTIVĒTO ZnO PĀRKLĀJUMU NANOMEHĀNISKĀS İPAŠĪBAS UN IESPĒJAMIE PIELIETOJUMI}

R. Zabels, F. Muktepāvela, M. Čubarovs

Kopsavilkums

Šajā darbā ir izpētìtas ar mehanoaktivētās oksidēšanas metodi iegūto $\mathrm{ZnO}$ pārklājumu uz stikla optiskās, elektriskās un nanomehāniskās īpašības. Veikts salīdzinājums ar $\mathrm{ZnO}$ monokristālu un ar magnetronu putinātajiem $\mathrm{ZnO}$ pārklājumiem. Rezultāti liecina, ka ar mehanoaktivêtās oksidēšanas metodi iegūtajiem pārklājumiem ir lieliska adhēzija ar pamatni, var veidoties graudaina struktūra ar cietību $8-10 \mathrm{GPa}$, kā arī var veidoties ar viskersiem pārklātas virsmas morfologija ar cietību līdz $18 \mathrm{GPa}$. Iegūto pārklājumu Junga modulis ir robežās no 80 $120 \mathrm{GPa}$, kas saskan ar rūpnieciski iegūto magnetronu putinātajiem ZnO pārklājumiem. Iegūto pārklājumu ar viskersu struktūru optiskās īpašības (absorbcija un luminiscence) atbilst tipiskiem augstas kvalitātes caurspīdīgiem $\mathrm{ZnO}$ pārklājumiem. Darbā paradīta iespēja izmantot iegūtos pārklājumus UV detektoros. 